\title{
The Political Rhetoric of Indian History
}

\author{
A Review Essay \\ James A. Clifton
}

American Indians, Time, and the Law, by Charles F. Wilkinson. New Haven: Yale University Press, 1987. 225 pp. $\$ 18.50$ cloth.

The Plains Indians of the Twentieth Century, edited by Peter Iverson. Norman: University of Oklahoma Press, 1985. 278 pp. $\$ 21.95$ cloth, \$9.95 paper.

The Iroquois Struggle for Survival: World War II to Red Power, by Laurence

M. Hauptman. Syracuse: Syracuse University Press, 1986. 328

pp. $\$ 37.50$ cloth, $\$ 15.95$ paper.

The Underground Reservation: Osage Oil, by Terry P. Wilson. Lincoln:

University of Nebraska Press, 1985. 263 pp. $\$ 22.95$ cloth.

EXCEPT for a few departures caused by premature deaths, all professional historians who have ever written about Indians are still pursuing their craft. Not surprisingly for a field barely a generation old, whose most seasoned masters lack the accumulated wisdom of intellectual parents, there are chronic expressions of doubt about aims, of a failure of consensus on methods and styles, and of confusion about purpose. ${ }^{1}$ What Indian history should be about remains at issue. Moreover, for modern historians, as for early nineteenth-century American national leaders, the Indian has proved to be a "perpetual harrow" on their professional sentiments, ${ }^{2}$ providing for too many a nearly irresistible opportunity to express alienation from America's past, and present. Thus, over its brief existence what Indian history has too often been is highly politicized rhetoric. ${ }^{3}$ More often than many practitioners may

1. Karen J. Winkler, "U.S. Historians Search for Proper Definition of American Indians," Chronicle of Higher Education, 15 April 1987.

2. Lynn H. Parsons, "A Perpetual Harrow Upon My Feelings': John Quincy Adams and the American Indian," New England Quarterly 46 (September 1973), 339-79.

3. One of the field's few stand-up critics is Wilcomb E. Washburn. See his "Distinguishing History from Moral Philosophy and Public Advocacy," in 
be willing to admit, the field's focal ancestress and model have been, perhaps half-consciously, Helen Hunt Jackson and her polemic, $A C e n-$ tury of Dishonor (1881).

Although mythography rather than proper history, Charles Wilkinson's American Indians, Time, and the Law provides the ideological framework that historians of Indian affairs must confront in fashioning their arguments. For Wilkinson's purpose-to persuade readers of the legitimacy of a particular legal doctrine, one founded on a carefully crafted image of the past-the history of America's native peoples falls into four periods. The pre-Columbian era of "tribal" or "national sovereignty," he indicates, was followed by a period when the separate Indian "nations" were segregated on reservations, then only to have imposed on them a policy of forced assimilation. The fourth era-encompassing only the past quarter century-is for this author the most significant, for in these years the "Indian" has risen up to reverse earlier policies and to establish viable "sovereignties" in "Indian country." Wilkinson sets out to provide a paramount doctrine of Indian law, which once established would sustain the many gains recently won by Indians in the federal courts. Fundamental to his argument is a much simplified view of the history of Indian affairs, and the image of the Indian as victim which is critical to its success.

Wilkinson's uses of the discipline amply illustrate what Alfred $\mathrm{H}$. Kelly has called "law-office history," the careful selection of only favorable facts and interpretations, to the exclusion of all else. ${ }^{4}$ But his abuse of history runs far past mere exploitation of data and constructions to buttress a law professor's brief, for he utterly denies the foremost principle of historical knowledge, the principle of change over time. If Americans are to hold their heads high in a world of other cultures, he argues, they must carry through with an ancient promise to protect and preserve Indian tribalism and separatism on the politically segregated ethnic homelands scattered across the face of the continent. Leaving aside the question of whether any such promise was ever made, Wilkinson would not only deny the possibility of social and cul-

Calvin Martin, ed., The American Indian and the Problem of History (New York, 1987).

4. "Clio and the Court: An Illicit Love Affair," Supreme Court Review, 1965, p. 145. See also Wilcomb E. Washburn, "History Reconsidered: The Supreme Court and the Use and Abuse of History," Organization of American Historians Newsletter 11 (August 1983), 7-9. 
tural change, he would use his doctrine to prevent it. His "history," therefore, is to the scholarship of historians as creation "science" is to modern evolutionary thinking.

Wilkinson sets out to sanctify and perpetuate the past quarter century of Indian victories in the federal courts. But those victories did not occur in a social or historical vacuum. These years were also marked by the institutionalization of the civil rights movement, the embodiment of anticolonialism as a moral code, the growth of narcissistic individualism, the politicization of scholarship, and the rise of the ethic of polyethnicity. Not unconnected to these has been the flowering in the American conscience of the Indian, periodically throughout American history the most favored of all underdogs and persistent, consummate model of a desirable alternative lifestyle. Wilkinson, a professional advocate for the Indian division of the American rights industry, ${ }^{5}$ may be excused his excesses. One expects such attorneys to promote the interests of their Indian clients without regard to truth or social consequences, since the key goal of their practice is winning. Whether such excesses can be tolerated of professional historians is a different issue.

Indian history as an organized field of study established its roots, such as they are, in the same quarter century. Thus its earliest practitioners fashioned their calling in a turbulent generation of extraordinary if transient excitement. So if there is a "problem" of Indian history, it is one of coping with multiple professional dilemmas, all involving the scholars' need to rise above the passions and the political pressures of their own era. Seeking the truth while using history rhetorically to contribute to "social change" has been the most common, if questionable, solution to the core paradox. Displaying a proper deference toward the "Indian," that is, treating the subjects of scholarship as clients to be extolled, is an associated posture, as is the corollary theme-to borrow Frederick E. Hoxie's phrase- of "ancestor bashing." ${ }^{\prime 6}$ It is the historian's forebears, not the Indians', who suffer the assaults, for a double standard of historical interpretation marks many of the volumes produced in the first generation of professional writing about the Indian past. Applauding the virtues of cultural relativism and ethnic multiplicity are also common motifs in such studies, reflecting efforts to infuse personal values into historical interpretations. Above all else,

5. See Richard E. Morgan, Disabling America: The "Rights Industry" in Our Time (New York, 1984).

6. Winkler, "U.S. Historians Search." 
numerous professional historians have avoided controversy by not asking the hard, taboo questions. What in the world, for instance, is the "Indian" about whom historians write? Whatever Indians were, are they today quite so impoverished or powerless as they are portrayed? Indeed, are many of them who they say they are? ${ }^{7}$

How well, then, do the three nonlitigious volumes covered by this review, those prepared by professional historians, fare when such questions are raised of their contents. Are they exemplars of meritorious historical scholarship? Are they, perhaps, models for what is, perhaps prematurely, being billed as the "new" Indian history? All three are marked by a concern with events impinging on Indians and Indian responses during the twentieth century, a period their authors claim has heretofore received too little attention. Two of them are marked by an additional concern-one that has nothing to do with the internal needs of the discipline, of plotting knowledge into the blank regions of its intellectual maps. Iverson introduces his anthology, for example, with the explicit acknowledgment that it was planned and published in response to a "challenge" to historians by Vine Deloria, Jr. Hauptman quotes precisely the same source and impetus in his opening pages. The urge to patronize an influential Indian celebrity is manifest. Whether specifically historical needs are served is a different issue.

IVERSON'S VOLUME is none too successful as regards the latter. It is, essentially, a cut-and-paste job containing eleven essays, eight of them reprints, the earliest first published scarcely more than twenty years ago, all easily available in standard sources. These include studies of various Plains Indian reservation communities and their responses to American policies in this century. The effects of the Dawes General Allotment Act and the consequences of Indian participation in World War II, for example, are featured. Included among these is an excerpt from Loretta Fowler's prize-winning book on the Northern Arapaho, which is not history proper but analytic ethnography, the only ac-

7. Notably, during the past few years, it has been the elder Indian historians who have begun asking sharp, politically sensitive questions. See Washburn, "History Reconsidered," and Robert F. Berkhofer's equally penetrating "Cultural Pluralism Versus Ethnocentrism in the New Indian History," in the same anthology; also, William T. Hagan's sterling "Full Blood, Mixed Blood, Generic, and Ersatz: The Problem of Indian Identity," Arizona and the West 27 (Winter 1985), 309-26. 


\section{Review Essay}

knowledgment that some scholars other than historians have been studying the experiences of Indians during this century.

Three of Iverson's selections are by nominal "Indians," including an essay by none other than the celebrity whose prompting sparked the volume in the first place, Vine Deloria, Jr. In his notes on contributors, the editor takes pains to label the public identities of these three as Standing Rock Sioux, Creek-Seminole-Sac-Fox-Shawnee, and Cherokee-Creek, while ignoring their composite Euroamerican ancestry. Such formalities are not observed for his other contributors, who are presumably generic "whites." This practice reflects both the double standard of identification practiced in such circumstances (non-Indians are simply "whites") and the etiquette of dealing with elite Indians, who do not care to have the Euroamerican components of their ancestry touted about. Such usage perpetuates the fiction of an America populated by mutually exclusive "races," one the victimizer, the other the victim. Who knows, perhaps Bill Hagan is tough-minded enough to have wanted equal time, to have had his Scots-IrishGerman-Hungarian tribal background at least mentioned, rather than to be stranded in a null category.

Unfortunately, their three essays do not compare well with the other eight. They read like the variety of history commonly taught in native American studies programs. Tom Holm, for example, makes much of the supposed "declaration of war" against the Axis powers by the New York Iroquois, which allows him to glamorize Iroquois "sovereignty." Lamentably, as Laurence Hauptman points out in his volume, this much-cited incident turns out to have been a public information stunt sponsored and stage-directed by the Office of War Information. Similarly, in an essay that reads like a prolegomenon to Wilkinson's volume, Vine Deloria, Jr., claims as "fundamental doctrine" that national legislation "has no application to Indians unless they are specifically mentioned" (emphasis in original). Hauptman, again, provides some of the necessary corrections to such law-office history, for he describes several instances where the New York Iroquois and other Indians discovered to the contrary, as in the federal right to condemn land for public purposes, and in the 1941 Iroquois opposition to the Selective Service Act. Such tales are apocryphal, not the stuff of history.

Whatever the initial lip service paid to the pronouncements of elite Indians and the constant use of obligatory code words, such as nation 
and sovereignty, Hauptman's thickly researched and carefully crafted study of the New York Iroquois communities (and their scattered congeners) from World War II to the era of Red Power stands in profound contrast to all such imitations of history. Hauptman is a professional scholar who has dedicated himself to writing the history of the New York Iroquois in this century, and this volume follows and improves on his valuable earlier book, The Iroquois and the New Deal. Since these Iroquois were prominently involved in all major Indian controversies and national developments from the 1940s through the 1970s, his volume is a major, lasting contribution to the social history of the United States and Canada. Unusual for an Indian historian, Hauptman is nearly hoax-proof and is certainly not stereotype-prone. He is hardheaded and courageous enough to emphasize that the Iroquois are among the most ethnocentric people known to social scientists, a fact central to fully understanding their history since the years when they rampaged over the eastern half of the continent imposing their imperialistic designs on others.

Yet even a professional with standards as high as those of Laurence Hauptman could not remain entirely free of the patronizing undercurrent of catch phrases and code words reflected prominently in the heavy language selected for his title. The book does not follow the connotations of its lead, an "Iroquois Struggle for Survival"; rather, Hauptman presents in thick description and sound, rich interpretation a portrait of a people determined to maintain their position of prestige and prominence, an "Iroquois Campaign to Prevail." The "survival" of Indians is a much abused catch phrase, reinforcing the stereotype of victimization. There has been no chance that the Iroquois would not survive in the past two centuries; rather, the issue has been, in what social shape and form, with what degree of clout and fame? Hauptman reports that they did nicely for themselves in these years; and his conclusions may now be updated. With the passage of Senate Concurrent Resolution 76 in September 1987, Congress has succumbed to pressures from the Iroquois and their allies by officially revising American constitutional history, making the League of the Iroquois the model used by the framers in drafting that document, thus transforming Iroquois ambition into American political myth.

Hauptman also falls victim to the tendency-common among writers of Indian history - to use this genre as an opportunity to sharpen personal axes. For example, in the Iroquois experiences during the 1950s, when their reserved lands were modestly affected by pro- 
grams of national internal improvements, he finds his opening for a shot at ancestor bashing. While other historians have favored Andrew Jackson or George Washington, even Thomas Jefferson or Abraham Lincoln, for such bombardments, Hauptman fixes on Dwight D. Eisenhower, whom he castigates for his "military style" management practices while president. Whatever Eisenhower may or may not have been while occupying the Oval Office, biographers and political historians of the period agree that he was an effective and efficient manager, a presidential capability not to be lightly disregarded in the late $1980 \mathrm{~s}$. The author here expresses a prejudice all too common among academics, a grave fear of the exercise of power in general and executive power in particular, a personal value that should be subject to some disciplined management in serious scholarship, no matter how favorably one's associates look on such exegesis.

TERRY P. WILSON'S STUDY of the Osage during this century falls into a form different from the other volumes reviewed. His is a book in a classic mold - the "tribal history" - and he sets out deliberately to work improvements on this well-established genre. Wilson, then, is a historian who seeks to benefit from the lessons of his own field's brief past, reaching for crescive intellectual development in method and style. On the whole he succeeds rather well, producing a narrative account that is generally illuminating and more than ordinarily contributory. The "Underground Reservation" his title refers to is the Osage oil and gas wealth, which these Indians reserved for their ownership when the provisions of the General Allotment Act were pressed on them early in this century. These reserved subsurface holdings have made the Osage fabulously wealthy, and the targets for some of the least savory of all American efforts to gain control of Indian resources.

The encounters of Osage with American in our century gave Wilson an opportunity to stress a standard theme in Indian history. The "noble Osage," as he portrays them, were debased, debauched, and deprived by the "rapacious white man." Given the high rates of intermarriage between the Osage and Euroamericans over the years, however, it is difficult to see how any scholar could long hold to a naive conception of a perpetual "natural" boundary between the Osage and the white "races" or ethnic groups. Although Wilson provides extensive evidence and commentary on the extraordinary amount of interbreeding between Osage Indians and Americans, his presentation is cast exclusively in the everyday language of "sixteenth-breeds" and 
"mixed-bloods," phrasings and constructions familiar and significant to the participants. Thus the author confuses what anthropologists call folk (or emic) constructs with generally applicable analytic (or etic) constructions, and misses an opportunity for genuinely penetrating cogitation.

A sharper, more objective analysis may have been made more difficult to achieve by this author's situation, due to his close affinities to the modern Osage, perhaps making him less independent than a scholar like Hauptman. Such involvements sometimes do not provide the distance needed for detached scholarly impartiality. Two other problems may also lay behind the absence of such analysis. Wilson's choice not to subject his large corpus of data about social change among the Osage to stricter theoretical analysis, for instance, might reflect not only the politicized constraints exercised by the Indian lobby, but certain of the predilections of Indian historiography itself. Notably more so than other fields of history, Indian historians remain essentially isolated from the main currents of twentieth-century social science thought, and they exhibit an extraordinary aversion to what is called the "jargon" (that is, the complex ideas and methods) of sociology and anthropology. In particular, Wilson's detailed but unanalyzed presentation of information about the changing patterns of Osage identity would have been illuminated by application of some of the recent concepts and findings about ethnicity. Obviously, most if not all contemporary "Osage" are Osage "by definition," but the definition of what constitutes an Osage has changed drastically in the past century, and these changes have been the consequence of manifest political and economic pressures. How such institutional forces influenced the creation of a greatly expanded, culturally heterogeneous "Osage" ethnic group this author does not make clear. ${ }^{8}$

If much Indian history is written as if common sense (that is, ethnocentric prescriptions) alone were enough to generate sound knowledge, it is also the one subfield of the discipline with the least demanding standards of preparation. In no other branch of history would such an absence of background expertise in the language and culture of the people subject to the scholar's examination be tolerated as is the rule in the doing of Indian history. Wilson's routine rendering of Osage language forms, such as "Ho-tah-moie" and "I'n-Shta-Heh," for example,

8. For alternative views, see Hagan's "Full Blood, Mixed Blood, Generic, and Ersatz"; also James A. Clifton, ed., Being and Becoming Indian: Biographic Studies of North American Frontiers (Chicago, in press). 
follow nineteenth-century amateur usage, not even the work of that century's early professional linguists, as if the genuine Osage commonly spoke in hyphenated syllables that followed the conventions of the English alphabet.

Overall,these four volumes represent a mixed bag. Although not properly history because it provides no trustworthy knowledge of the past, Wilkinson's effort to persuade readers of the moral inevitability of a separate political and legal status for "Indians," whatever their ancestry and heritage, is significant reading for anyone interested in contemporary legal-political currents. His is an agenda for the future, a well-crafted legal myth, and his pronouncements may not easily be dismissed. Some may read through his pages and find a disturbing utopian vision of a future United States, where each ethnic group or cluster of alternative life-stylers is incorporated as a separate sovereignty, a nation carved up into hundreds of petty Monacos or Liechtensteins. ${ }^{9}$ Iverson's anthology, on the other hand, will be of value mainly to those who do not have access to a decent library. Apparently prepared at the behest of representatives of the Indian lobby (as Wilkinson's was in service to his clients), it will not likely prove to be of lasting value. Celebrities such as Deloria do not press scholars to issue forth in search of dispassionate truth. Their academic associates are thought of as political allies obligated to produce materials that reinforce the goals of their lobby. More than a few, apparently, go astray by mixing political with scholarly aims.

Such caveats have only limited application to studies such as Terry Wilson's study of the vicissitudes of the Osage and their oil and gas riches, or Laurence Hauptman's examination of the Iroquois' efforts to sustain and enhance their already prestigious image in the twentieth century. Whatever criticisms may be made of their passing defects, these are serious works of scholarship and will have lasting value. Both represent long commitments to quality scholarship and a dedication to deep archival digging and clear thinking.

9. Some thoughts on the plans the Indian rights lobby has for the future United States are in James A. Clifton, "Old Northwest Indian Removal, Internal Development, and the Patronage Process: Underlying Institutional Patterns," a paper presented in the Symposium on Native Americans and the Metropole, Annual Meeting of the American Anthropological Association, December 1986. 
Yet even in these two fine studies of fragments of the American experience over the recent century, we can see that the young field of Indian history is seriously cumbered in practice. While limited by weaknesses of disciplinary and substantive preparation, such authors are further constrained by a heavy burden of accumulated stereotypes and conventional themes and phrases, which too often leak through to mar their writing. Pressed externally by figures in the community who demand conformity to particular views of the past, and made hesitant by the conservatism of university presses laboring under similar constraints from the communities they serve, they too easily avoid the tough questions and taboo topics. Vine Deloria, Jr., may have asked too much in demanding that historians concentrate on the history of Indians in this century. Recent history is difficult history to write, if for no other reason, as Sir Walter Raleigh discovered to his great misfortune, than that one's clients and patrons are apt to turn and snap at the nonconforming author's heels. So we can appreciate how it is that, even in the most serious scholarship, the cant of conventional political rhetoric is at times overwhelming. 
Copyright of Annals of Iowa is the property of State of Iowa, by \& through the State Historical Society of Iowa and its content may not be copied or emailed to multiple sites or posted to a listserv without the copyright holder's express written permission. However, users may print, download, or email articles for individual use. 